\title{
HMOX1 Gene
}

National Cancer Institute

\section{Source}

National Cancer Institute. HMOX1 Gene. NCI Thesaurus. Code C43314.

This gene is involved in heme catabolism and cellular homeostasis. 